\title{
A novel approach for preventing esophageal stricture formation: olmesartan prevented apoptosis
}

\author{
Murat Dereli' ${ }^{1}$, Bartlomiej E. Krazinski ${ }^{2}$, Suleyman Ayvaz' ${ }^{1}$, Burhan Aksu', \\ Mehmet Kanter ${ }^{3}$, Hafize Uzun ${ }^{4}$, Remise Gelisgen ${ }^{4}$, C. Hasan Umit ${ }^{5}$, Mustafa İnan ${ }^{1}$, \\ Umit Nusret Basaran ${ }^{1}$, Mehmet Pul ${ }^{1}$
}

\author{
${ }^{1}$ Department of Pediatric Surgery, Trakya University Faculty of Medicine, Edirne, Turkey \\ ${ }^{2}$ Department of Human Histology and Embryology, Faculty of Medical Sciences, University \\ of Warmia and Mazury, Olsztyn, Poland \\ ${ }^{3}$ Department of Histology and Embryology, Faculty of Medicine, Trakya University, Edirne, Turkey \\ ${ }^{4}$ Department of Biochemistry, Cerrahpasa Faculty of Medicine, Istanbul University, Turkey \\ ${ }^{5}$ Department of Gastroenterology, Faculty of Medicine, Trakya University, Edirne, Turkey
}

\begin{abstract}
Accidentally ingested corrosive substances can cause functional and structural damage to the esophageal tissue resulting in stricture formation. It has been reported that the administration of olmesartan (OLM) can have anti-inflammatory, antifibrotic and antiapoptotic effects on injured tissue. The aim of our study was to check if OLM could prevent formation of scars in the corrosive esophageal burn model. Fifty-one Wistar Albino rats were divided into six groups: Control, Sham, OLM, Sham + OLM, Burn, and Burn + OLM. Olmesartan (5 $\mathrm{mg} / \mathrm{kg}$ ) was given by gavage once per day for 21 consecutive days after injury. The morphology of the esophagus was assessed after Masson trichrome staining, and apoptosis was evaluated using the terminal deoxynucleotidyl transferased UTP nick end labeling (TUNEL) method. The serum nucleosomes (as an indicator of apoptosis), serum $\mathrm{p} 53$ protein, and esophageal tissue p53 protein levels of each group were measured by immunoassays. Muscularis mucosa damage, submucosal collagen deposition, and tunica muscularis injury in the Burn + OLM group decreased significantly compared with the Burn group $(p<0.05)$. Similarly, the number of apoptotic cells in the Burn + OLM group decreased compared with the Burn group $(\mathrm{p}<0.05)$. Serum levels of nucleosomes and p53 and tissue of p53 protein did not differ between the groups. Exogenously administered OLM can effectively prevent the occurrence of esophageal strictures caused by corrosive esophageal burns. (Folia Histochemica et Cytobiologica 2014, Vol. 52, No. 1, 29-35)
\end{abstract}

Key words: corrosive esophageal burn; stricture; olmesartan; protection; apoptosis; TUNEL; nucleosomes; p53

\section{Introduction}

Caustic esophageal burns in both children and adults remain an important cause of morbidity and mortality around the world [1]. The burns can occur in the

\footnotetext{
Correspondence address: Ayvaz M.D.,

Trakya Universitesi, Tip Fakultesi,

Cocuk Cerrahisi AD, 22030, Edirne-Turkey

tel.: + 902842357641 ; fax: + 902842357652 ;

e-mail: suleyayvaz@yahoo.com
}

mouth and larynx and can cause extreme damage to the organs, resulting in loss of voice, difficulty in swallowing, and airway obstruction [1]. Long-term complications include the deposition of collagen and stricture formation. The latter can also increase gastroesophageal reflux and predispose to esophageal carcinoma [2]. Thus, one of the most important goals in treating of corrosive esophageal burns is to prevent the stricture formation. Several types of nonsurgical stricture techniques have been proposed, including dilatation, esophageal stent placement, total parenteral nutrition, steroids, and antibiotic therapy $[1,2]$. 
However, none of these treatment modalities seems to be effective in the treatment of severe caustic esophageal burns $[1,2]$.

Angiotensin II and its receptor type 1 (AT1R) together with its downstream mediators are involved in immune and inflammatory responses and they can contribute to the generation of oxidative stress, regulation of cell growth and cell death and promotion of tissue remodeling. Inhibition of AT1R signaling can attenuate cellular stress and provide beneficial effects to the injured tissue [3, 4]. Olmesartan (OLM) is AT1R antagonist. In diabetic rat model of liver fibrosis OLM was found to be the most protective among tested AT1R blockers [5]. However, the effects of OLM on esophageal tissue regeneration and fibrosis after corrosive esophageal burns have yet not been studied.

Therefore, the aim of our study was to evaluate the effects of OLM on wound healing and stricture formation in the rat esophagus after caustic injury.

\section{Material and methods}

Animals and experimental protocol. The Trakya University guidelines for the care and use of laboratory animals were followed, and ethical committee consent was obtained for the study. Fifty-one female Wistar Albino rats weighing 200-250 g each were randomly assigned to six groups: Control $(n=6)$, Sham $(n=8)$, OLM $(n=8)$, Sham + OLM $(\mathrm{n}=8)$, Burn $(\mathrm{n}=12)$, and Burn $+\operatorname{OLM}(\mathrm{n}=9)$. The rats in Sham and Sham + OLM groups underwent esophageal dissection only, while the rats in Burn and Burn + OLM groups underwent both esophageal dissection and experimental esophageal burn formation.

The rats were anesthetized with ketamine and xylazine administered i.p. (50 mg/kg and $10 \mathrm{mg} / \mathrm{kg}$, respectively). Caustic esophageal injury was produced using the Liu and Richardson [6] modification of the experimental model of Gehanno and Guedon [7]. Briefly, after a median laparotomy, a $1.5-\mathrm{cm}$ segment of the distal esophagus was exposed, and an 8 Fr feeding catheter with an outer diameter of $0.22 \mathrm{~cm}$ was placed into the distal esophagus via the oral route. A similar catheter was placed into the distal esophagus via gastrotomy. The catheters were secured, and an isolated segment of the distal esophagus was obtained. The distal catheter was clamped, and the isolated segment was distended by infusion of $25 \% \mathrm{NaOH}$ at an intraluminal pressure of $10 \mathrm{~cm} \mathrm{H}_{2} \mathrm{O}$ for two minutes, until a slight translucency of the esophageal wall and branching of the vessels were noted. Following this procedure, the distal catheter was unclamped, and the esophagus was rinsed with $40 \mathrm{~mL}$ of distilled water. The gastrotomy and laparotomy were subsequently closed.

Immediately after the formation of the esophageal burn in the Burn + OLM group, the administration of OLM
( $5 \mathrm{mg} / \mathrm{kg}$ daily) through gavage began and was continued for 21 days. A similar OLM treatment was applied to the OLM and Sham + OLM groups. After the surgery, all animals were kept on a standard rodent pellet diet with tap water $a d$ libitum, and $10 \mathrm{~mL}$ of $0.9 \% \mathrm{NaCl}$ was administered subcutaneously for the first three postoperative days. Twenty one days after the initial treatment, rats were anesthetized and blood was collected for biochemical assays. The esophagus was opened longitudinally, and the injured area was removed and divided into two pieces. One sample was fixed in $4 \%$ neutral-buffered formaldehyde solution, whereas the other sample was kept at $-80^{\circ} \mathrm{C}$ until further biochemical analyses. All the rats were subsequently euthanized with a high dose of phenobarbital.

Assessment of esophageal tissue. Esophageal tissues were examined under a light microscope at the Trakya University Faculty of Medicine, Histology and Embryology Department's Light Microscopic Laboratory. For this purpose, the esophageal tissues were fixed for four days in neutral-buffered $10 \%$ formalin solution. Then, tissues were washed for two days in $70 \%$ alcohol and processed into paraffin blocks using a standard procedure. Using a Leica RM-2245 microtome, $6 \mu \mathrm{m}$ thick sections were stained using the Masson trichrome method. The deposition of submucosal collagen in the esophageal wall and muscular mucosa and the depth of the injury were assessed and scored semi-quantitatively as described previously [8].

Evaluation of apoptotic cells by the TUNEL method. The apoptosis of the fibroblasts of esophageal submucosa was evaluated using the terminal deoxynucleotidyl transferased UTP nick end labeling (TUNEL) technique [9]. The $6 \mu \mathrm{m}$ thick sections were placed in the oven at $37^{\circ} \mathrm{C}$ overnight, and afterwards were thoroughly cleared of paraffin and rehydrated in decreasing concentrations of ethanol. Thereafter, sections were incubated at room temperature for 15 minutes in proteinase $\mathrm{K}$ solution $(20 \mathrm{mg} / \mathrm{mL}$, Cat. no. 21627, Chemicon International, Temecula, CA, USA). The sections were washed with distilled water, and then in the solution of methanol in $3 \% \mathrm{H} 2 \mathrm{O} 2$ for five minutes to block the endogenous peroxidase activity. Later, the sections were incubated with the terminal deoxynucleotidyl transferase enzyme (Cat. no. S7100, Chemicon) in the oven at $37^{\circ} \mathrm{C}$ for one hour. The anti-digoxigenin sections were also washed with PBS three times for 10 minutes. Diaminobenzidine dissolved in PBS was applied at room temperature for 30 minutes. The sections were washed again in distilled water for ten minutes, and methyl green staining was performed. The sections were then dehydrated with toluol for 2-3 minutes, cover-slipped, and evaluated by light microscopy. To count the TUNEL-positive cells in the esophageal tissue, the ocular micrometer compatible with an Olympus BX51 microscope was used. TUNEL-positive cells were counted 
under a 100-square ocular micrometer (eye piece graticule; eyepiece $\times 10$, objective $\times 40$ ). In each section, the number of cells in ten different, randomly selected areas were counted, and the arithmetic mean was calculated. For the $\times 40$ magnification, the 100 -square micrometer area was determined by means of a micrometer slide. Finally, all counts were expressed as the number of TUNEL-positive cells per unit area $\left(\mathrm{mm}^{2}\right)$.

Determination of nucleosome concentration in the serum. The serum nucleosomes level (mono- and oligonucleosomes as indicators of apoptosis) was determined using the ELISA kit (Cat. no. 11774425001; Roche, Maharashtra, India), according to the manufacturer's instructions.

Determination of $\mathrm{p53}$ protein contents in esophageal tissue and the serum. Prior to biochemical measurements, the esophageal tissue samples were weighted and added to 10-fold quantity of cold potassium phosphate buffer $(\mathrm{pH} 7.4)$ and homogenized using a glass homogenizer at $4^{\circ} \mathrm{C}$. The homogenates were centrifuged at $10.000 \mathrm{rpm}$ at $4^{\circ} \mathrm{C}$, and the supernatants were separated. The concentrations of p53 protein in esophageal tissue homogenates and in the serum were assessed using the ELISA kit (Cat. no. 11828789001; Roche Molecular Biochemicals, Mannheim, Germany) according to the manufacturer's instructions.

Statistical analysis. The data was analyzed using a commercially available statistical software package (SPSS 15.0, SPSS Inc., Chicago, IL, USA). The normal distribution of the variables was tested using a one-sample Kolmogorov-Smirnov test. For variables with normal distribution, the differences among the groups were compared using one-way ANOVA followed by the Bonferroni post-hoc test if a significant difference was found. The Kruskal-Wallis test was used for non-normal distributed data. Dual comparisons between the groups that were significantly different were evaluated using the Mann-Whitney $\mathrm{U}$ test. The results are presented as means $\pm \mathrm{SEM}$, and $p$ values less than 0.05 were regarded as statistically significant.

\section{Results}

\section{Assessment of esophageal tissue stained by Masson trichrome method}

Changes that occurred in the esophageal tissue after the corrosive esophageal burns were examined according to the criteria and scores shown in Table 1 . In the Burn group the muscular layer exhibited a higher number of fibroblasts, increased collagen deposition between muscle bundles and reduced thickness as compared with the intact esophagus of control group (Figure $1 \mathrm{~B}$ and $1 \mathrm{~A}$, respectively). However, in the
Table 1. Histopathological evaluation criteria and scores of esophageal damage according to Türkyilmaz et al. [11]

\begin{tabular}{|l|c|}
\hline Criteria & Score \\
\hline Increased submucosal collagen deposition & 0 \\
\hline None & $1+$ \\
\hline $\begin{array}{l}\text { Mild (submucosal collagen at least twice } \\
\text { the thickness of the muscularis mucosa) }\end{array}$ & $2+$ \\
\hline $\begin{array}{l}\text { Marked (submucosal collagen more than twice } \\
\text { the thickness of the muscularis mucosa) }\end{array}$ & 0 \\
\hline Presence of injury in the muscularis mucosa & $1+$ \\
\hline None & \\
\hline Present & $1+$ \\
\hline $\begin{array}{l}\text { Presence of injury and collagen deposition } \\
\text { in the tunica muscularis }\end{array}$ & $2+$ \\
\hline None & 0 \\
\hline Mild (collagen deposition around myocytes) & $\begin{array}{l}\text { Marked (same as mild, with collagen deposition } \\
\text { replacing some myocytes) }\end{array}$ \\
\hline
\end{tabular}

Burn + OLM group collagen fiber deposition and number of fibroblast between muscle cells were reduced as compared with the Burn group (Figure 1C and $1 \mathrm{~B}$, respectively). The results of semiquantitative histopathologic evaluation of esophageal tissues showed that the submucosal collagen deposition, muscularis mucosa damage, and tunica muscularis damage scores of the Burn + OLM group were found to be significantly lower than those of the Burn group $(p<0.005, p<0.005$, and $p<0.002$, respectively; Table 2).

\section{Assessment of apoptosis in the esophageal tissue}

The results of the TUNEL staining of fibroblasts in the submucosa of esophageal wall are shown in Table 3 and Figure 2. The average number of apoptotic cells was significantly reduced in the Burn + OLM group as compared to the Burn group ( $p<0.005$; Table 2$)$. At the same time, the average number of apoptotic cells in the Burn and Burn + OLM groups were higher than in the other groups (Control, Sham, OLM, and Sham + OLM; $p<0.002$ and $p<0.003$, respectively; Table 2).

\section{Biochemical measurements}

The serum concentrations of nucleosomes and p53 protein as well as the contents of p53 protein in esophageal tissue were similar in all experimental groups and did not differ significantly (Table 4). 


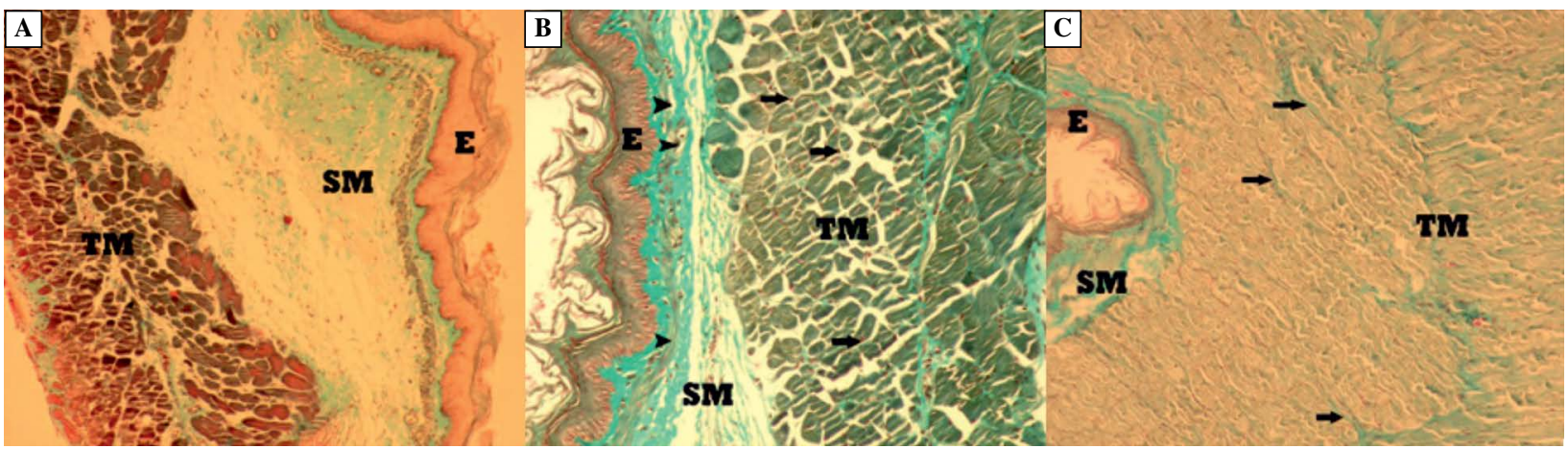

Figure 1. Histologic appearance of esophagus stained by Masson trichrome method. A. Normal esophagus (control group), $\times 200$; B. Burn group: in the muscle layer an increased number of fibroblasts is seen (arrows) and the thickness of the muscularis mucosa (arrowheads) is reduced, $\times 400$; C. Burn + OLM group: the reduction of connective tissue (arrows) in the muscle layer of esophageal wall is clearly visible, as well as reduced number of fibroblasts, $\times 400$. Symbols: $\mathrm{E}-$ epithelium; SM — submucosa; TM - tunica muscularis

Table 2. Semiquantitative histopathologic evaluation of esophageal tisues based on Masson trichrome staining

\begin{tabular}{|l|c|c|c|c|c|c|}
\hline & Control & Sham & OLM & S+OLM & Burn & Burn+OLM \\
\hline Submucosal collegen deposition & $0.00 \pm 0.00$ & $0.00 \pm 0.00$ & $0.00 \pm 0.00$ & $0.00 \pm 0.00$ & $1.58 \pm 0.19^{*}$ & $0.78 \pm 022$ \\
\hline Muscularis mucosa injury & $0.00 \pm 0.00$ & $0.00 \pm 0.00$ & $0.00 \pm 0.00$ & $0.00 \pm 0.00$ & $1.00 \pm 0.00^{*}$ & $0.44 \pm 0.18$ \\
\hline $\begin{array}{l}\text { Tunica muscularis injury and } \\
\text { collagen deposition }\end{array}$ & $0.00 \pm 0.00$ & $0.00 \pm 0.00$ & $0.00 \pm 0.00$ & $0.00 \pm 0.00$ & $1.67 \pm 0.14^{* *}$ & $0.56 \pm 0.24$ \\
\hline Total score & & & & & $4.25 \pm 0.33^{* *}$ & $1.89 \pm 0.51$ \\
\hline
\end{tabular}

Description of groups as in Methods. Values are expressed as mean \pm SD, scores were obtained according to the criteria presented in Table 1. *, **significantly different from Burn+OLM group, $\mathrm{p}<0.005$ and $\mathrm{p}<0.002$, respectively.

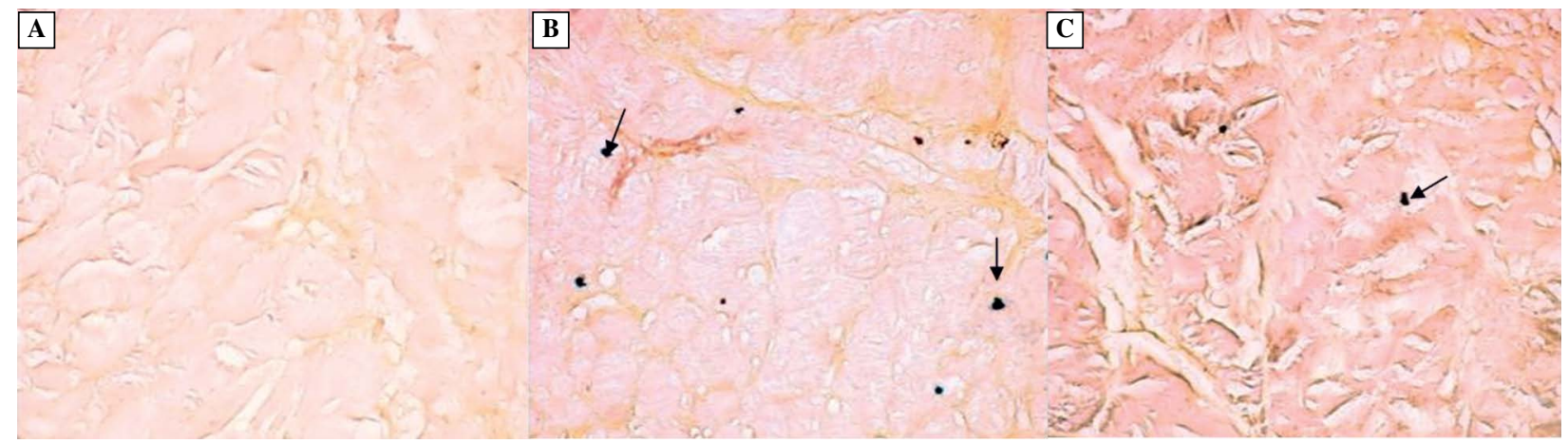

Figure 2. Presence of apoptotic cells in esophageal tissue visualized by TUNEL method. A. Control rat, lack of apoptotic cells; B. Burn group: increased number of TUNEL-positive cells; C. Burn + OLM group: lower number of TUNEL positive cells as compared with the Burn group. Symbols: arrows, TUNEL positive cells. $\times 400$

Table 3. The number of apoptotic cells in esophageal tissues of the studied groups

\begin{tabular}{|c|c|c|c|c|c|}
\hline Control & Sham & OLM & S+OLM & Burn & Burn+OLM \\
\hline $3.32 \pm 0.75$ & $3.64 \pm 0.90$ & $3.82 \pm 0.70$ & $3.50 \pm 1.38$ & $56.17 \pm 0.90^{* \#}$ & $31.22 \pm 1.17^{\dagger}$ \\
\hline
\end{tabular}

Apoptosis was assessed by the TUNEL method as described in Methods. Values are expressed as mean \pm SD. Description of groups as for Table 2. ${ }^{*}$ significantly different from Control, Sham, OLM and S+OLM groups, $\mathrm{p}<0.002 ;{ }^{*} \mathrm{p}<0.005$ compared with Burn +OLM; ${ }^{\dagger}$ significantly different from Control, Sham, OLM and S+OLM groups, $\mathrm{p}<0.003$ 
Table 4. The concentrations of nucleosomes and p53 and tissue level of p53 protein in esophageal tissue

\begin{tabular}{|l|c|c|c|c|c|}
\hline & Sham & OLM & S+OLM & Burn & Burn+OLM \\
\hline Serum nucleosomes $(\mathrm{mU} / \mathrm{ml})$ & $7.17 \pm 3.64$ & $3.43 \pm 0.59$ & $2.45 \pm 0.32$ & $4.68 \pm 0.96$ & $24.93 \pm 15.57$ \\
\hline p53 tissue content $(\mathrm{pg} / \mathrm{g}$ wet tissue) & $3008.3 \pm 481.5$ & $3829.8 \pm 1104.8$ & $2446.0 \pm 438.5$ & $2821.9 \pm 594.5$ & $2028.6 \pm 571.4$ \\
\hline p53 serum level $(\mathrm{pg} / \mathrm{ml})$ & $47.84 \pm 10.46$ & $96.01 \pm 32.87$ & $42.18 \pm 14.21$ & $156.54 \pm 61.91$ & $40.88 \pm 15.70$ \\
\hline
\end{tabular}

Description of groups as for Table 2. Serum concentration of nucleosomes and p53 protein as well as p53 protein content in tissues were measured as described in Methods. Values are expressed as mean \pm SD. There were no statistically significant differences between groups, $p>0.05$

\section{Discussion}

Esophageal burn caused by corrosive substances initially leads to acute necrosis and thrombosis with consequent ischemia and hypoxia, which are followed by the inflammation and oxidative stress [1,2]. Prolonged stressful conditions are caused by the release of proinflammatory cytokines (and growth factors) as well as the exposure to reactive oxygen species (ROS). Both can result in an excessive activation and proliferation of fibroblasts but also in increased rate of cell death $[3,10]$. By the second and third week after the caustic injury, collagen deposition begins and fibrosis followed by stricture formation may occur [2]. It is well documented that after the cell injury, the renin-angiotensin system, particularly the signaling mediated by angiotensin II receptor type I, is essential for the activation of NADPH oxidase, stimulates secretion of pro-inflammatory and profibrotic cytokines and exerts a direct mitogenic effect on fibroblasts [3, 4]. Thus, we decided to investigate the putative influence of treatment with olmesartan, an AT1R blocker, on fibrosis and apoptosis in the rat model of esophageal caustic burn. The administration of OLM started immediately after the injury and was continued during the next 21 days, including second and third week of tissue repair, i.e. recovery period during which collagen deposition and formation of strictures occur.

The results of the present study provide the first demonstration that the treatment with OLM can effectively prevent fibrosis and limit the damage to the esophageal tissue in the animal model of caustic burn. We also demonstrated that administration of OLM can reduce proliferation of fibroblasts and deposition of collagen induced by the injury. Moreover, we found that OLM can have anti-apoptotic properties and significantly limit injury-evoked apoptosis in the esophagus.

In recent years several experimental studies have shown that OLM-mediated AT1R inhibition can provide beneficial effects in respect to the excessive collagen deposition which leads to fibrosis and tissue remodeling. OLM was found to inhibit peritoneal fibrosis and loss of mesothelium in a laboratory model of hypertensive rats subjected to continuous peritoneal dialysis [11]. Inhibition of AT1R in a rat model of nonalcoholic steatohepatitis resulted in a significant reduction of the activation of stellate (Ito) cells, oxidative stress and the expression of liver fibrosis-related genes: transforming growth factor- $\beta 1$ (TGF- $\beta 1$ ) and collagen genes [12]. OLM was also successfully tested as a potential antifibrotic drug in another experimental model of liver fibrosis [13]. It was shown that the inhibition of AT1R suppressed the proliferation of stellate cells, collagen synthesis and expression of profibrogenic cytokines such as TGF- $\beta 1$ and connective tissue growth factor (CTGF) by activated stellate cells. AT1R antagonism appeared to attenuate collagen synthesis, fibrosis and structural remodeling in rabbit model of atrial fibrillation and it was proposed that OLM acted through the inhibition of p38MAPK/ERK pathway in cardiac fibroblasts [14]. Furthermore, in the canine model of atrial fibrillation, interstitial fibrosis was caused by the AT1R-dependent up-regulation of strong mediator of ECM synthesis, CTGF, and this effect was partially abolished by OLM [15].

The anti-fibrotic properties of OLM cannot be dissociated from its anti-apoptotic and anti-necrotic effects which play a protective role in injured tissues. For instance, OLM administered after a myocardial infarction attenuated injury-evoked up-regulation of BAX protein, Fas receptor and Fas ligand [16]. Similarly, the induction of TNF- $\alpha$ expression in the rat model of steatohepatitis was limited by the inhibition of AT1R signaling by OLM [15]. In a study of experimental autoimmune myocarditis OLM prevented apoptosis by decreasing the levels of mediators of oxidative stress, endoplasmic reticulum stress, and cardiac inflammatory mediators [17]. It was also documented that anti-apoptotic action of OLM in perivascular injury and hepatic steatosis can be mediated by inhibition of the apoptosis signal regulating kinase 1 (ASK1) [18].

The presented study is the first one which demonstrated anti-apoptotic effect of OLM on injured 
esophageal tissue. The number of TUNEL-positive apoptotic cells decreased in the esophagus of OLM -treated animals, however, the levels of the $\mathrm{p} 53$ protein were similar between the experimental groups. The local tissue injury did not affect serum levels of p53 protein and nucleosomes in the OLM-treated animals. It was documented that the activation of $\mathrm{p} 53$ protein (and its downstream proteins) in cultured myocytes correlated with the activation of renin-angiotensin system mediated by AT1R [19]. The ability of p53 protein to bind DNA and induce apoptosis in these cells was abolished by the treatment with AT1R blocker, losartan [19]. Thus, the pro-apoptotic action of p53 is mediated rather by changes in its activity and binding properties than quantity. Moreover, the p53 protein has a very short half-life period (several minutes) [20]. These two facts can explain why we did not find any differences between experimental groups in the tissue and serum levels of the p53 protein.

Tissue-protective effects of OLM were demonstrated in studies carried out on rats subjected to subtotal nephrectomy. Morphological and functional symptoms of progressive renal injury induced in these rats were alleviated by the inhibition of AT1R [21, 22, 23]. Similarly, the treatment with OLM significantly attenuated the number of TUNEL-positive cells in the animal model of progressive glomerular injury [23] and in the kidneys of hypertensive rats [24]. Moreover, in both cited studies, OLM-reduced apoptosis was associated with lower degree of interstitial fibrosis or glomerular sclerosis, respectively. Authors of the above-mentioned studies suggested that beneficial role of OLM was associated rather with its antioxidant properties than antihypertensive action on renal cardiovascular system. The latter suggests that the anti-fibrotic and anti-apoptotic effects of OLM administration in esophageal caustic burn observed in our study could be also attributed to the suppression of oxidative stress by AT1R antagonism. This hypothesis is in agreement with the results of previous studies which demonstrated partially successful treatment of caustic esophageal burns by increasing the antioxidant capacity of the tissue [25-35]. The present study provides new evidence that the renin-angiotensin system can be a promising target for the treatment of esophageal burns caused by corrosive agents.

In conclusion, our results confirm that administration of OLM can reduce pro-fibrotic and pro-apoptotic stimuli evoked by caustic esophageal burn. Based on the results of ours and other studies we demonstrate that the treatment with OLM can have direct impact on the formation of stenosis in esophageal caustic burn, possibly due to anti-inflammatory and antioxidant properties of OLM. Further studies are needed to unravel the mechanisms of anti-fibrotic and anti-apoptotic action of OLM in the esophageal tissue.

\section{Acknowledgments}

This study was supported as a Project TUBAB by Trakya University Research Center, Edirne, Turkey.

\section{References}

1. Lupa M, Magne J, Guarisco JL, Amedee R. Update on the Diagnosis and Treatment of Caustic Ingestion. Ochsner J. 2009;9:54-59.

2. Contini S, Scarpignato C. Caustic injury of the upper gastrointestinal tract: a comprehensive review. World J Gastroenterol. 2013;19:3918-3930.

3. Rosenbloom J, Mendoza FA, Jimenez SA. Strategies for anti-fibrotic therapies. Biochim Biophys Acta. 2013;1832:1088-1103 .

4. Zhang W, Wang W, Yu H et al. Interleukin 6 underlies angiotensin II-induced hypertension and chronic renal damage. Hypertension. 2012;59:136-144.

5. Sipal S, Halici Z, Kiki I et al. Comparative study of three angiotensin II type 1 receptor antagonists in preventing liver fibrosis in diabetic rats: stereology, histopathology, and electron microscopy. J Mol Histol. 2012;43:723-735.

6. Liu AJ, Richardson MA. Effects of N-acetylcysteine on experimentally induced esophageal lye injury. Ann Otol Rhinol Laryngol. 1985;94:477-482.

7. Gehanno P, Guedon C. Inhibition of experimental esophageal lye strictures by penicillamine. Arch Otolaryngol. 1981;107:145-147.

8. Türkyilmaz Z, Sönmez K, Demirtola A et al. Mitomycin C prevents strictures in caustic esophageal burns in rats. J Surg Res. 2005;123:182-187.

9. Kressel M, Groscurth P. Distinction of apoptotic and necrotic cell death by in situ labelling of fragmented DNA. Cell Tissue Res. 1994;278: 549-556.

10. Kannan K, Jain SK. Oxidative stress and apoptosis. Pathophysiology. 2000;7:153-163.

11. Nakamoto H, Imai H, Fukushima R et al. Role of the renin -angiotensin system in the pahtogenesis of peritoneal fibrosis. Perit Dial Int. 2008;28(Suppl. 3):S83-87.

12. Hirose A, Ono M, Saibara T et al. Angiotensin II Type 1 Receptor Blocker Inhibits Fibrosis in Rat Nonalcoholic Steatohepatitis. Hepatology. 2007;45:1375-1381.

13. Kurikawa N, Suga M, Kuroda S, Yamada K, Ishikawa H. An angiotensin II type 1 receptor antagonist, olmesartan medoxomil, improves experimental liver fibrosis by suppression of proliferation and collagen synthesis in activated hepatic stellate cells. Br J Pharmacol. 2003;139:1085-1094.

14. Fujita M, Cheng XW, Inden Y et al. Mechanisms with clinical implications for atrial fibrillation-associated remodeling: cathepsin $\mathrm{K}$ expression, regulation, and therapeutic target and biomarker. J Am Heart Assoc. 2013;2:e000503.

15. Kiryu M, Niwano S, Niwano $\mathrm{H}$ et al. Angiotensin II-mediated up-regulation of connective tissue growth factor promotes atrial tissue fibrosis in the canine atrial fibrillation model. Europace. 2012;14:1206-1214.

16. Kanamori H, Takemura G, Li Y, Okada H, Maruyama R, Aoyama T. Inhibition of Fas-associated apoptosis in granulation tissue cells accompanies attenuation of postinfarction left ventricular remodeling by olmesartan. Am J Physiol Heart Circ Physiol. 2007;292:2184-2194. 
17. Sukumaran V, Watanabe K, Veeraveedu PT et al. Olmesartan, an AT1 antagonist, attenuates oxidative stress, endoplasmic reticulum stress and cardiac inflammatory mediators in rats with heart failure induced by experimental autoimmune myocarditis. Int J Biol Sci. 2011;7:154-167.

18. Yamamoto E, Dong YF, Kataoka K et al. Olmesartan prevents cardiovascular injury and hepatic steatosis in obesity and diabetes, accompanied by apoptosis signal regulating kinase-1 inhibition. Hypertension. 2008;52:573-580.

19. Atadja P, Wong H, Garkavtsev I, Veillette C, Riabowol K. Increased activity of $\mathrm{p} 53$ in senescing fibroblasts. Proc Natl Acad Sci U S A. 1995;92:8348-8352.

20. Levine AJ, Momand J, Finlay CA. The p53 tumour suppressor gene. Nature. 1991;351:453-456.

21. Kadowaki D, Anraku M, Tasaki Y et al. Evaluation for antioxidant and renoprotective activity of olmesartan using nephrectomy rats. Biol Pharm Bull. 2009;32:2041-2045.

22. Takahashi T, Konta T, Takasaki S, Ichikawa K, Takeishi Y, Kubota I. An angiotensin II type-I receptor blocker, olmesartan medoxomil, attenuates lipid peroxidation in renal injury induced by subtotal nephrectomy. Clin Exp Nephrol. 2007;11:202-208.

23. Fujimoto S, Satoh M, Horike H et al. Olmesartan ameliorates progressive glomerular injury in subtotal nephrectomized rats through suppression of superoxide production Hypertens Res. 2008;31:305-313.

24. Uramatsu T, Nishino T, Obata Y et al. Involvement of apoptosis inhibitor of macrophages in a rat hypertension model with nephrosclerosis: possible mechanisms of action of olmesartan and azelnidipine. Biol Pharm Bull. 2013;36:1271-1277.

25. Basaran UN, Eskiocak S, Altaner S, Ture M, Yapar SB. Inhibition of iNOS with S-methylisothiourea was impaired in wound healing in caustic esophageal burn. Int J Pediatr Otorhinolaryngol 2005;69:471-477.

26. Kiyan G, Aktas S, Ozel Ket al. Effects of Hyperbaric Oxygen Therapy on Caustic Esophageal Injury in Rats.J Pediatr Surg. 2004;39:1188-1193.

27. Guven A, Gundogdu G, Sadir S et al. The efficacy of ozone therapy in experimental caustic esophageal burn. J Pediatr Surg. 2008;43:1679-1684.

28. Uguralp S, Irsi C, Aksoy T et al. Resveratrol attenuatesin flammation and stricture formation in experimental caustic esophageal burns. Pediatr Surg Int. 2008;24:425-430.

29. Yukselen V, Karaoglu AO, Yenisey C et al. Trimetazidine reduces the degree of fibrosis in alkali burns of the esophagus. J Pediatr Surg. 2005;40:505-509.

30. Herek O, Karabul M, Yenisey C, Erkuş M. Protective effects of ibuprofen against caustic esophageal burn injury in rats. Pediatr Surg Int. 2010;26:721-727.

31. Bakan V, Garipardic M, Okumuş M et al. The protective effect of erythropoietin on the acute phase of corrosive esophageal burns in a rat model. Pediatr Surg Int. 2010;26:195-201.

32. Larios-Arceo F, Ortiz GG, Huerta M et al. Protective effects of melatonin against caustic esophageal burn injury in rats. J Pineal Res. 2008;45:219-223.

33. Ocakci A, Coskun O, Tumkaya L et al. Beneficial effects of Ebselen on corrosive esophageal burns of rats. Int J Pediatr Otorhinolaryngol. 2006;70:45-52.

34. Makay O, Yukselen V, Vardar E et al. Role of allopurinol on oxidative stress in caustic burn: cure for stricture? Pediatr Surg Int. 2007;23:1105-1112.

35. Günel E, Caglayan F, Caglayan O, Canbilen A, Tosun M. Effect of antioxidant therapy on collagen synthesis in corrosive esophageal burns. Pediatr Surg Int. 2002;18:24-27.

Submitted: 24 July, 2012 Accepted after reviews: 9 April, 2014 